\section{Case of postpartum axial spondyloarthritis}

In a recent issue of the Annals of Rheumatic Diseases, Hoballah et al reported high false-positive results on sacroiliac MRI based on the Assessment of SpondyloArthritis international Society (ASAS) criteria in the early postpartum period. ${ }^{1}$ Similarly, Renson et al reported a markedly high prevalence of postpartum sacroiliac bone marrow oedema on sacroiliac MRI and recommended waiting at least 6 months after delivery to perform sacroiliac MRI. ${ }^{2}$ Both studies excluded patients with inflammatory bowel disease. We would like to share below a case of new onset axial spondyloarthritis in an early postpartum patient with ulcerative colitis.

A Japanese female patient in her 30s with ulcerative colitis in clinical remission without treatment was evaluated for a 2 -month history of progressive right buttock pain which began 6 months after childbirth. Naproxen was ineffective in relieving the pain.

Physical examination showed tenderness in the right sacroiliac joint and was positive for Patrick's test and Gaenslen test. Laboratory analysis showed serum $\mathrm{C}$ reactive protein $1.7 \mathrm{mg} / \mathrm{dL}$ and was negative for human leucocyte antigen-B27. A plain radiograph of the sacroiliac joint was normal. MRI revealed bone marrow oedema without erosion or ankylosis in the right sacroiliac joint, thus satisfying the ASAS criteria for active sacroiliitis (figure 1A). The pain dramatically improved 4 days after adalimumab treatment was begun, and the MRI findings improved by week 8 (figure 1B).

In patients with inflammatory bowel disease, mechanical stress on the sacroiliac joint during labour may induce persistent inflammation leading to axial spondyloarthritis. Although the

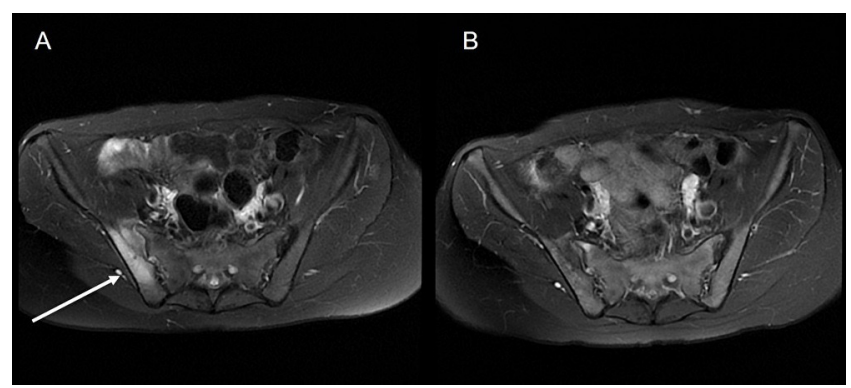

Figure 1 (A) bone marrow oedema in the right sacroiliac joint on short tau inversion recovery images at baseline; (B)improvement of bone marrow oedema after treatment.
MRI findings are indistinguishable from non-specific bone marrow oedema, response to treatment can confirm the diagnosis of postpartum axial spondyloarthritis. In cases with a high index of suspicion, clinical diagnosis and prompt treatment can improve the patient's quality of life.

Kazunori Furuhashi, ${ }^{1}$ Nanase Honda, ${ }^{2}$ Yuji Miyoshi, ${ }^{2}$ Naoto Yokogawa $\odot{ }^{1,2}$

${ }^{1}$ Department of Internal Medicine, Hino Municipal Hospital, Hino, Japan

2Department of Rheumatic Diseases, Tokyo Metropolitan Tama Medical Center, Fuchu, Japan

Correspondence to Dr Naoto Yokogawa, Department of Rheumatic Diseases, Tokyo Metropolitan Tama Medical Center, Fuchu 183-8524, Japan; yokogawan@aol.com

Contributors $\mathrm{KF}$ and $\mathrm{NY}$ contributed to the conception and drafting of the article. $\mathrm{KF}, \mathrm{NH}, \mathrm{YM}$ and NY provided critical revision for important intellectual content and final approval.

Funding The authors have not declared a specific grant for this research from any funding agency in the public, commercial or not-for-profit sectors.

Competing interests None declared.

Patient and public involvement Patients and/or the public were not involved in the design, or conduct, or reporting, or dissemination plans of this research.

Patient consent for publication Obtained.

Provenance and peer review Not commissioned; internally peer reviewed.

(c) Author(s) (or their employer(s)) 2020. No commercial re-use. See rights and permissions. Published by BMJ.

\section{Check for updates}

To cite Furuhashi K, Honda N, Miyoshi Y, et al. Ann Rheum Dis Epub ahead of print: [please include Day Month Year]. doi:10.1136/annrheumdis-2020-218587

Received 17 July 2020

Accepted 18 July 2020

\section{Sinked}

http://dx.doi.org/10.1136/annrheumdis-2020-218687

Ann Rheum Dis 2020;0:1. doi:10.1136/annrheumdis-2020-218587

ORCID iD

Naoto Yokogawa http://orcid.org/0000-0002-7814-443X

\section{REFERENCES}

1 Hoballah A, Lukas C, Leplat C, et al. Mri of sacroiliac joints for the diagnosis of axial spa: prevalence of inflammatory and structural lesions in nulliparous, early postpartum and late postpartum women. Ann Rheum Dis 2020;79:1063-9.

2 Renson T, Depicker A, De Craemer A-S, et al. High prevalence of spondyloarthritis-like MRI lesions in postpartum women: a prospective analysis in relation to maternal, child and birth characteristics. Ann Rheum Dis 2020;79:929-34. 